International Journal of Children's Rights, 25: 307-319

\title{
Common criticisms of children's rights and 25 years of the IJCR
}

Priscilla Alderson

\begin{abstract}
In this $25^{\text {th }}$ anniversary volume of the International Journal of Children's Rights, responses are reviewed to common criticisms of children's rights, within the Journal's aims to promote greater understanding of these rights and greater practical respect for them. This article then considers three main ways through which the Journal might expand its work in future: more analysis of the positions that underlie opposition to children's rights; more connections with "adult" rights; and more attention to future needs and rights.
\end{abstract}

\section{Keywords}

Climate change, complexity, duties, feminism, indigenous rights, living rights, misunderstandings, NGOs, philosophy, postmodernism, post-colonialism, values, violations, women's rights

\section{Introduction}

Over the past 25 years, the main contributions that the International Journal of Children's Rights (IJCR) has made to demonstrate the complexity and diversity of children's rights are in: 1) the broad range of topics and in how rights cover all aspects of children's lives, 2) the geographical scope and variety spanning across the world, and 3) the examples from all social disciplines and research methods and theories that can help to illuminate these rights. IJCR reports and promotes many vital connections between concepts of rights and their actual practice, between universal principles and local understandings, between interpretations and implementation of rights.

The phrase "common criticisms" appears in the title of this paper to echo the title of an earlier paper (Alderson 2000), which is still among the most often viewed online of my publications. Who, I wonder, are all the critics that keep these readers so busy? Are they lecturers who believe that the proper academic study of children's rights must be through critique? Or are they critical members of the professions or the general public to whom readers wish to respond? The phrase "criticisms of children's rights" shows millions more hits on Google than "criticisms of women's rights" or "of human rights", and adults are far better able to defend their own rights in public and private than children are able to do. So not surprisingly, IJCR has been much concerned with responding to common criticisms, misunderstandings and misrepresentations of children's rights. After reviewing and responding to some criticisms of children's rights, this article considers three ways forward through which IJCR might expand its work: more analysis of positions that underlie criticisms of children's rights; more contact with "adult" rights; and more attention to children's future needs and rights. 


\section{Positions that underlie criticisms of children's rights}

Reports in the IJCR tend to defend children and their rights and to show how important they are, and one main way of doing so is to respond to the critics. There appeared to be a rise in respect for children's rights around 1990 shown, for instance, in governments ratifying the UNCRC (UN 1989) in unprecedented numbers. The African Charter on the Rights and Welfare of the Child was adopted by the Organisation of African Unity in 1990. English common law in the 1985 Gillick case $^{1}$ and also the 1989 Children Act ${ }^{2}$ influenced law and standards in over 50 countries in the (formerly British) Commonwealth of Nations, where around 2.3 billion people now live. The medico-legal case Gillick on the competent child was discussed as applying to diverse aspects of children's lives, among others by the Children's Legal Centre in London and its journal ChildRIGHT, the Children's Rights Alliance for England (CRAE) and the youth movement Article 12. The first volume of IJCR appeared in 1993.

However, the "backlash" against Gillick", undermining respect for competent children, had already begun in $1991^{3}$ and has grown in influence along with a perceived fall in respect for children's rights. Today, schools have become far more coercive, numbers of school student exclusions have soared since 1990, numbers of young people in prison doubled around 1997, children's amenities and services have especially suffered from the austerity cuts, while the rise in debt and housing costs, and the fall in wages and secure employment especially increase poverty among young people and young families.

The fall in respect for children's rights may be traced alongside a general decline in workers' and trade union rights, in citizen's privacy rights and access to justice in Britain, with recent massive cuts in legal aid, besides access to healthcare also following huge cuts besides costly privatisation. There is the steep rise of self-harm and suicides in prisons denoting worsening conditions for prisoners and staff that inevitably erode dignity and respect, and many other regressions. Much of this is associated with growing inequality; Oxfam annually reports that each year fewer rich individuals own as much as half the people in the world own; by 2017 these were only eight multi-billionaires. ${ }^{4}$ Equal human dignity and rights are increasingly challenged when wealth is so unequally distributed.

Every year, CRAE (2016) expertly documents numerous violations that attack children's rights. Cost-cutting in childcare, education, health and social services reduces the numbers of staff, and the time they can take to get to know children individually, to listen to them and work with them respectfully to solve problems. This is all part of global moves towards valuing market values over democratic ones and cost-effective profit over people, so that the present state of children's rights needs to be understood in the political and economic contexts.

\footnotetext{
${ }^{1}$ Gillick v Wisbech \& W. Norfolk HA [1985] 3 All ER 423).

2 The 1989 Children Act England and Wales, with similar Acts for Scotland and Northern Ireland, state that children deemed to be competent can 'refuse medical or psychiatric examination'. The Age of Legal Capacity (Scotland) Act, 1991 s2 (4) clarified that children can be deemed Gillick competent if they are assessed as competent by the treating doctor.

${ }^{3}$ Lord Donaldson in the Court of Appeal ruled that $R$, aged almost 16 and refusing mental health treatment, could be forced to have medication (In re R [1991] 4 All ER 177). In 1992 he ruled that W, aged 16, who had anorexia could be force-fed against her wishes (In re W [1992] 4 All ER 627).

4 http://policy-practice.oxfam.org.uk/our-work/inequality
} 
Nevertheless there are also common misunderstandings and criticisms of children's rights, broadly based on conscious or subconscious values as well as beliefs about the nature of childhood and of rights. The political economist Professor Lord Plant (2014) pronounced, "Children cannot be citizens with rights, because they cannot make rational choices. They can be adherents to a religious faith only indirectly through their parents' religion." The average age of the unelected House of Lords is well over 70, and their dubious place in a democracy is further compromised by their limited capacity to serve the youngest generations in Britain. To which they might reply that democracy involves only adult voters not children.

If the negative values and concepts about childhood remain unrecognised and unquestioned, children remain dangerously submerged below the level of mainstream debates, decisions and policy making. Much work is needed to inform the public, adults and children alike (UNCRC 1989, Article 42), parents, professionals and policy makers about what rights actually involve and why they matter. IJCR has responded a great deal to this challenge, notably, for example, in Michael Freeman's (2007) strong advocacy, partly in response to critics such as Guggenheim (2005). The next sections consider not so much detailed objections to children's rights, but the assumptions and positions from which certain critics view children's rights, which could perhaps be addressed more fully in future volumes of IJCR. When rights are not only misunderstood but the misunderstandings are ignored or denied, there is even less hope for progress.

"Children's rights should be about duties, and not just let children do whatever they want."

Ignorance about rights underlies much of the opposition to them. It misunderstands that rights are not about 'doing whatever I want', but instead they are deeply serious basic standards of justice that support everyone's life and wellbeing. To claim a right involves the duty of respecting everyone else's equal claim to that basic right, whether to "adequate nutritious foods and clean drinking-water" (UNCRC Article 24), or to protection from "torture or other cruel, inhuman or degrading treatment or punishment" (Article 37), or to "freedom to seek, receive and impart information and ideas of all kinds". Rights respect "the rights or reputations of others...national security" and public "order, health and morals" (UNCRC Article 13 and see other Articles and UN Conventions). It is ironic and tragic that in the age of selfish neoliberalism, rights are misrepresented as selfish, instead of being recognised as the strongest challenges to neo-liberalism and "the ethical architecture necessary to decent everyday life" (Gearty 2011). The remedy for ignorance is to read UN Conventions and the IJCR.

\section{"Yes of course we respect children's rights!"}

Too often, many who make this claim do not understand rights, and confuse them with needs, welfare and best-interests, defined and serviced by adults who assume they know best. This complacence excludes children and their rights from much mainstream debate and policy, besides local, national and international activities intended to benefit children. For example, at a well-attended national conference about children's rights for university lecturers of educational psychology, when asked, not one person said they had read the UNCRC. Yet the "state party" (the government with individuals and groups working on its behalf) including the state employed lecturers are required by the UNCRC to plan and provide services based on children's rights and to educate others about them. Educational psychologists 
have great power over identifying children with special needs and referring them for services, and also over encouraging inclusive or segregated schools. Over 6,000 disabled children attend 287 special residential schools in England (DfE, 2014), often far from their home, which lessens their chances during their childhood and adulthood to "enjoy a full and decent life, in conditions which ensure dignity, promote self-reliance and facilitate the child's active participation in the community" (UNCRC Article 23). The right to family life was misrepresented at the conference as being honoured when the school becomes "the child's family". Teachers cannot possibly replace life-long parents. One place at special boarding school can cost over $£ 3$ million. If they were offered an informed choice, how many families would choose less costly and proper local support? But many professionals withhold information and disrespect families' decision making.

Research in 17 of the boarding schools (the only ones that allowed access by the researchers, so what were the other 270 like?) presented very disturbing evidence of loss and failure (Pellicarno 2015). It was sponsored by the Children's Commissioner for England (the only one in the world not to be a children's rights commissioner or to comply with the Paris Principles) who wrote a bland congratulatory foreword about the importance of listening to children. A favourite evasion by children's supposed advocates is to emphasise their listening, but not their findings or any practical responses.

NGOs are among the foremost child rights advocates. Yet when NGO members present rights as simplistic uniform rules, instead of complex universal principles that are open to local interpretations, such as when NGOs claim that the UNCRC bans child labour (it does not), then they can unfortunately increase opposition to children's rights and so offer the critics strong, albeit misinformed, anti-rights arguments.

"We are objective value-free researchers and professionals concerned with evidence and outcomes not with norms or ethics like rights."

Positivist and objective researchers claim that utility and cost-effectiveness are value-free, although they actually involve market values, rules and targets that can partly exclude and conflict with the values of human rights, freedom and dignity. Internationally, governments reveal this conflict when they favour making trade agreements with very oppressive regimes above diplomatically challenging these regimes' human rights violations. This "objective" stress on ends (outcomes) risks overlooking the means and processes towards those ends, so that oppressive processes may be excused.

\section{"As philosophers, we respect the rational person."}

A long tradition in philosophy identifies the human person with those attributes we do not share with other species, such as verbal reasoning and politics. Not only does the tradition present a falsely narrow idea of humanity by excluding almost all our feeling-thinking-relating- interdependent-vulnerable human qualities, it is aided by outdated child development theories that especially exclude young children as notyet-fully-human (for example, Archard and Macleod, 2004 reviewed in IJCR, 15,3-4: 415-8). Rights then tend to be seen mainly as the thoughts of Enlightenment philosophers and lawyers.

An alternative history of rights is that they emerged from age-old protests across the world by the common people, adults and children, against oppression and injustice, from the accounts in the $8^{\text {th }}$ Century BCE of the Israelites' escape from 
slavery in Egypt up to industrial strikes by children and adults in the $20^{\text {th }}$ Century CE (Cunningham and Lavalette 2016). From the $17^{\text {th }}$ Century onwards, the people's claims for justice have gradually been defined by philosophers into a range of specific rights, which during the $20^{\text {th }}$ Century have been extended to all human groups including children. This latter view recognises two essential elements of common rights. First, they express deep human longings that everyone should enjoy liberty, equality, solidarity and dignity.

Second, today's international human rights (UN 1948; CE 1950) did not emerge from Rational Enlightenment Man but from the need to protect vulnerable people, adults and children, from such atrocities as the Holocaust (Sands 2016). Far too often, children's rights are discussed on trivial levels, distracting attention from the rights of millions of children who currently endure extreme problems. The Archard and Macleod book connects protection rights to the incompetent child, instead of recognising, first, that vulnerability and the need for protection occur at any age or level of competence and, second, that adversity can greatly increase children's maturity and informed competence to exercise their rights (Alderson 1993). Another example is the right to play, which is usually seen as a children's right, instead of being related to all-age human rights, when adults play games, sports and music: "Everyone has the right to rest and leisure, including reasonable limitation of working hours and periodic holidays with pay" (UN 1948, Article 24). IJCR needs to continue its work of advocating greater understanding of the real philosophy and meaning of rights.

"As feminists, we have problems with children's rights."

Children have much to learn from women's long history of being oppressed and campaigning for rights. Women and children have both been unfairly excluded for similar excuses - that they are too emotional, ignorant, weak, dependent or irrational to be rights holders. Women are children's main advocates, but the great solidarity between the two groups is complicated by tensions (Twamley et al., 2016). Children and their dependency and need for adults' time and care are often seen as the major barriers to women's freedoms and fulfilment of their own rights, so that "childcare" (in contrast to living alongside children) comes to be seen as labour, to be measured, priced and delegated rather than valued and enjoyed.

When women as adult rights-holders refuse to be "treated like children" they risk implying that it is acceptable for children to be oppressed and humiliated. Since children are fairly seldom heard in their own right, ways in which their emancipation has been both advanced but also complicated and held back by their dependence on women's advocacy need much further analysis.

"UNCRC was written by adults. Children's rights should be rewritten by children." All the human rights Conventions could no doubt be improved and updated. However, this view about rewriting has been set under the heading of criticisms of children's rights for three main reasons. First, if a new and perhaps more clear and radical UNCRC were to be published, in today's divided world few governments are likely to ratify it so that it would be weak and useless in its work of actively defending children's rights. There would certainly no longer be the present unanimous worldwide support with the sole exception of the USA, or the system of accountability through governments' regular reports to the UN Committee, ${ }^{5}$ weak though that is.

\footnotetext{
${ }^{5}$ For details see http://www.ohchr.org/EN/HRBodies/CRC/Pages/CRCIndex.aspx
} 
Second, rights are more than wish-lists. They are extremely carefully crafted philosophical, political and legal statements, honed and tested over many decades, as well as ratified and enacted through many levels of law and governance. Adults have relied on specialists to record and ratify their rights; they have not treated writing rights as a DIY activity, and neither should children. Adults who encourage children to write-your-own-rights appear to misunderstand the true meaning and powerful politics and structures of internationally agreed rights.

Third, far from being empowering or emancipating as claimed (for example, Arce 2012), instead, misleading teaching sessions on rights-writing replace vital political activity. This kind of DIY exercise cannot possibly, as claimed, "advance an emancipatory discourse of [children's] rights where they become legislators by achieving authoritative, norm-creating capacity" (Arce, 2012, p. 365) because children are not legislators, not even voters, and to suggest to them that they are legislators betrays them.

Lessons in rights-writing divert street children, working children, and others in great need of interpreting and campaigning for their rights, away from these crucial tasks: to see how their specific local rightful claims connect to statements in the agreed Conventions and can be promoted through them; and to campaign for practical recognition of their rights by their government and agencies at all levels. Children and young people often do this through inventive ways that appeal to the public imagination (Popović 2015).

Arce (2012) commends the African Working Children's Movement who produced 12 rights, though he does not quote them. Yet the list shows how such exercises are unhelpful in that 11 of the 12 rights are already in the UNCRC, so why spend children's precious time trying to reinvent the wheel? The sole exception is " 3 : The right to stay in the village (not to migrate)". The wording is unrealistic in that it does not allow for the possibility of floods or famine, whereas rights have to involve possibilities that can be willed by the individuals concerned and enforced, such as by the courts.

However, the children's desire to stay in their village raises crucial protests against worldwide urbanisation, with people being driven off their land into cities, and land being stolen, sold and privatised. The UN (2007) Declaration on the Rights of Indigenous Peoples Article 10 backed up by others of the 46 Articles, carefully rewords the "The right to stay in the village" is realistic terms, which can be legally enforced in national and international law when "forcibly" means conscious intended human force:

Indigenous peoples shall not be forcibly removed from their lands or territories. No relocation shall take place without the free, prior and informed consent of the indigenous peoples concerned and after agreement on just and fair compensation and, where possible, with the option of return.

Instead of trying to draft alternative statements, children would gain far more by working on the Conventions and the Declaration, to give meaning to them by interpreting them within their complex local contexts (van Daarlen et al., 2013) and thereby increasing everyone's understanding of children's potentially powerful rights.

\section{"As social constructionists or postmodernists we cannot accept the reality of} universal rights." 
A range of social science theories challenges human and children's rights. Social constructionism by seeing everything emerging from its local context denies there can be universal values, while postmodernism questions the essential reality of everything. These approaches illustrate how, besides addressing the immediate arguments posed against children's rights, the underlying theories on which they are based also need to be addressed to see how valid, convincing and realistic they are. For example, do researchers deny that rights can be universal in theory, but in practice assume that they personally should have the right to be protected from unjust imprisonment, rape and murder? This sets up an unrealistic and unjust conflict between professional theory and personal practice, besides indefensible assumptions that rights apply to some people but not to others. Porpora (2016) argues that researchers should resolve such illogical conflicts, and he recommends basic commitments for all social scientists. These include: recognition of the inherent truth and values in all social life and research; respect for individuals as embodied conscious agents (rights holders) interacting within powerful social structures (including inequalities and the rights that challenge them);and explicit clarity about the underlying theories and assumptions in the research. Porpora's work is valuable in helping us to question not only the criticisms of children's rights, but also beliefs behind how and why critics arrive at their conclusions, a potential topic for future issues of IJCR.

\section{Children's rights and "adult" rights}

A second future emphasis for IJCR could be to increase connections between children's and "adult" or broadly human social, economic and political rights. It can be helpful to see that opposition to human rights, let alone to children's rights, is widespread. The UK Labour government reluctantly passed the 1998 Human Rights Act, and almost immediately began to criticise it (Chakrabarti, 2014), while the Conservatives threaten to repeal the Act and end all connections with the European Court of Human Rights and the European Convention on Human Rights (CE, 1950). There are false claims that human rights support dangerous rights for prisoners, allow hate speech, enable judges in London and Strasburg to overrule the British Parliament, and are unrealistic left-wing fantasies, whereas the creation of the $E C H R$ was led by British lawyers actively supported by Winston Churchill's government (Gearty 2016).

Among the widespread fears about falling respect for rights by the British and USA governments are concerns that they will no longer defend human rights against oppressive regimes around the world. The United Nation's vital promotion of human rights is also at risk, with four of the five permanent members of the Security Council (Putin, Xi, Trump and May) all being openly hostile critics, and they were almost joined in 2017 by Marine Le Pen.

If the common ground shared by the UNCRC with the other human rights treaties about protecting and providing for vulnerable needy human beings is missed, the UNCRC may mistakenly be criticised, for example, as "indebted to specific EuroAmerican adult understandings which picture the child as ignorant, innocent and needy" (Arce, 2012); Arce's emphasis on "the child" challenges Western overindividualism. Yet all laws and treaties refer to individuals, to "everyone" and "no one". Paradoxically, mention of each individual is the only way to transcend individualism by ensuring universal and equal inclusion: "No one shall be held in 
slavery or servitude...No one shall be subjected to torture or to cruel, inhuman or degrading treatment or punishment...Everyone has the right to freedom of opinion and expression...Everyone has the right to freedom of peaceful assembly and association" (UN 1948, Articles 4-5, 19-20). To respect each embodied individual is the only defence for all against starvation, discrimination, torture and murder.

The lawyer Conor Gearty (2011) sees human rights as "the only contemporary idea with true universal and progressive appeal", too important to leave to political parties or the markets. Rights are one of the few present ethical resources we have, in the Western "post-socialist, post-religious haze of market supremacy", when rights respect everyone's dignity through structures of accountability to an independent rule of law, community self-government and, especially, equity. Gearty considers that rights connect wealthier Minority world countries to the energetic radicalism of the poorer Majority world and their claims to rights to be free from tyranny, exploitation and oppression. By aligning children's with human rights, the Journal can further its promotion of the urgency and seriousness of the UNCRC.

\section{Rights and the future}

Articles in IJCR based on empirical research and literature reviews provide vital material for analysing the present state of children's rights. Yet they tend to be backward looking and a third way forward for IJCR could be to consider more prospects and challenges for children's rights over the next 25 years. Numerous (allage-related) reports predict very bleak futures with: potentially great problems in finance, industry and trade; increasing poverty and inequality; greatly ageing populations needing costly support; automation and other technological change that will destroy millions of jobs; climate change eroding growth and prosperity while creating immeasurable new problems of deadly storms, floods and droughts and ensuing violent conflict and migration; the increase of nuclear and other arms.

Dire reports about the millions of child refugees highlight how young migrants are especially at risk of illness and injury, of being lost, abandoned or kidnapped, and left destitute. The UN has warned that globally there are 60 years of harvest left before the top soil is lost to pollution and erosion. ${ }^{6}$ Meanwhile ever more of the interdependent plant and animal species are vanishing, including bees and other pollinators on which we all depend. One list of impending disasters concludes:

One of the peculiarities of this complex, multi-headed crisis is that there appears to be no "other side" on to which we might emerge. It is hard to imagine a realistic scenario in which governments lose the capacity for total surveillance and drone strikes; in which billionaires forget how to manipulate public opinion; in which a broken EU reconvenes; in which climate breakdown unhappens, species return from extinction and the soil comes back to the land. These are not momentary crises, but appear to presage permanent collapse. ${ }^{7}$

\footnotetext{
${ }^{6}$ https://www.scientificamerican.com/article/only-60-years-of-farming-left-if-soil-degradationcontinues/

${ }^{7}$ https://www.theguardian.com/commentisfree/2016/nov/25/13-crises-we-face-trump-soil-loss-globalcollapse
} 
How do children's rights activists, lecturers and researchers counter this global avoidance and denial? We could concentrate more on macro policies as well as local experiences, and draw interconnected themes together rather than examining each one separately (Alderson 2016).

Levitas (2010) contends that the $19^{\text {th }}$ Century founders of sociology assumed that social research is utopian, both in criticising present practices and also in proposing better alternatives. The UNCRC is a valuable and detailed utopian map that envisages everyone being adequately cared for, protected from serious harms, and flourishing together in equality, justice and freedom. The IJCR could invite more forward-looking articles on using children's rights to work with children and young people on transforming societies and promoting peace and justice.

\section{References}

African Charter on the Rights and Welfare of the Child (Addis Ababa, African Union, 1990).

Alderson, P., Children's Consent to Surgery. (Buckingham: Open University Press, 1993).

Alderson, P., The Politics of Childhoods Real and Imagined (London: Routledge, 2016).

Arce, M. C., Towards an emancipatory discourse of children's rights, International Journal of Children's Rights, 2012 (20) 365-421.

Archard, D. and Macleod, C. (eds) The Moral and Political Status of Children

(Oxford: Oxford University Press, 2004).

CE - Council of Europe, European Convention on Human Rights (Strasbourg, EC, 1950).

Charabarti, S. On Liberty (London: Allen Lane, 2015).

CRAE - Children's Rights Alliance for England., State of Children's Rights in

England, in 8 Briefings (London: CRAE, 2016).

Cunningham, S. and Lavalette, M. Schools Out! The Hidden History of Britain's

School Strikes (London, Bookmarks. 2016).

DfE - Department for Education. Schools, Pupils and their Characteristics. (London: DfE, 2014).

Freeman, M. Why it remains important to take children's rights seriously, International Journal of Children's Rights, 2007 (15) 5-23.

Gearty, C., On Fantasy Island: Britain, Europe and Human Rights (Oxford: Oxford University Press, 2016).

Guggenheim, M., What's Wrong with Children's Rights? (Cambridge MA: Harvard University Press, 2005).

Levitas, R. Back to the future: Wells, sociology, utopia and method, Sociological Review, 2010 (58) 530-47.

Pellicarno, E., Hill, V., Croydon, A., Greathead, S., Kenny, L. \& Yates, R. My Life at School: Understanding the Experiences of Children and Young People with Special Educational Needs in Residential Special Schools (London: UCL Institute of Education, 2015).

Plant, R. Lecture on the Liberal Society and Religion. London: Gresham College, 28 January, 2014. 
Popović, S. and Miller, M., Blueprint for a revolution: How to Use Rice Pudding, Lego Men and Other Non-Violent Techniques to Galvanise Communities (London: Scribe, 2015).

Porpora, D., Reconstructing Sociology: The Critical Realist Approach (Cambridge: Cambridge University Press, 2015).

Sands, P., East West Street: On the Origins of Genocide and Crimes against Humanity (London: Weidenfeld \& Nicholson, 2016).

Twamley, K., Rosen, R. and Mayall, B., The (im)possibilities of dialogue across feminism and childhood scholarship and activism, Children's Geographies, 2016, DOI: 10.1080/14733285.2016.1227611.

UN., Universal Declaration of Human Rights (New York: UN, 1948).

UN., United Nations Convention on the Rights of the Child (New York: UN, 1989).

UN., Declaration on the Rights of Indigenous Peoples. New York: UN, 2007).

Van Daarlen, E., Hanson, K. And Neiuwenhuys, O., Children's rights as living rights, IJCR (24) 803-25, 2013. 